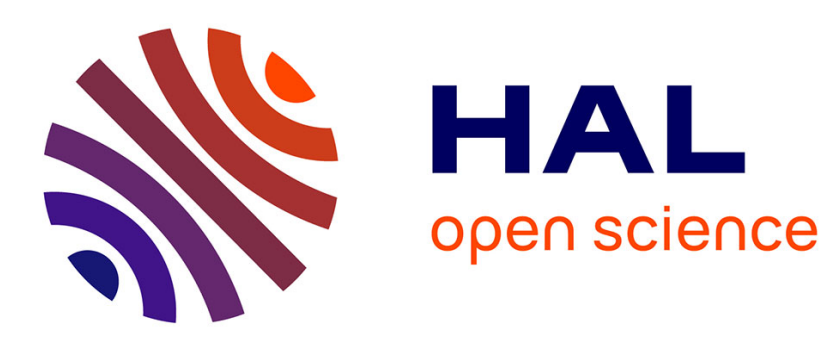

\title{
Agricultural Prices, Selection, and the Evolution of Food Industry
}

Carl Gaigné, Leo Le Mener

\section{To cite this version:}

Carl Gaigné, Leo Le Mener. Agricultural Prices, Selection, and the Evolution of Food Industry. [University works] auto-saisine. 2012, 26 p. hal-01208918

\section{HAL Id: hal-01208918 \\ https://hal.science/hal-01208918}

Submitted on 6 Jun 2020

HAL is a multi-disciplinary open access archive for the deposit and dissemination of scientific research documents, whether they are published or not. The documents may come from teaching and research institutions in France or abroad, or from public or private research centers.
L'archive ouverte pluridisciplinaire HAL, est destinée au dépôt et à la diffusion de documents scientifiques de niveau recherche, publiés ou non, émanant des établissements d'enseignement et de recherche français ou étrangers, des laboratoires publics ou privés. 


\title{
RéseauSPAANetwork
}

Structure et la Performance de l'Agriculture et de l'industrie des produits Agroalimentaires
Structure and Performance of Agriculture and Agri-products industry Network

\section{Agricultural Prices, Selection, and the Evolution of Food Industry}

\author{
Carl Gaigné ${ }^{1}$ \\ INRA, UMR1302 SMART, Rennes (France) and \\ Université Laval, CREATE, Québec (Canada). \\ Email: carl.gaigne@rennes.inra.fr
}

\section{Léo Le Mener}

INRA, UR1134 LERECO, Nantes (France) and Université de Rennes II, EA 2241, CIAPHS, Rennes (France).

Email: Leo.Le.Mener@nantes.inra.fr

Cahier de recherche/Working paper \#2012-5

\footnotetext{
${ }^{1}$ This paper was largely written while Carl Gaigné was an invited Professor at Université Laval (Canada) during 2011 and 2012. Carl Gaigné thanks the Centre de Recherche en économie de l'Environnement, de l'Agroalimentaire, des Transports et de I'Energie (CREATE) for financial support and Bruno Larue for his hospitality and helpful discussions.
} 


\title{
Agricultural Prices, Selection, and the \\ Evolution of Food Industry
}

\begin{abstract}
In this paper, we set up a simple model that explains the relation between low input price, high exit rates and industrial concentration. More precisely, we argue that falling input prices force firms with low productivity to exit and induce expansion of more efficient incumbents at the expense of less productive producers. Our model helps reconcile some well-established empirical results regarding the food processing industry. Indeed, agricultural prices have been declining between the early 1900s until 2006 while, over the same period, concentration and firm productivity have been increasing in the agri-food industry.
\end{abstract}

\section{Résumé}

Nous analysons l'incidence de réductions dans les prix des intrants sur le taux de sortie d'entreprises et le niveau de concentration industrielle. Les bas prix profitent davantage aux entreprises très productives et forcent la sortie d'entreprises moins productives. Ce phénomène est observé dans l'industrie de la transformation agroalimentaire. D'importantes baisses de prix ont été observées pour les produits primaires entre le début des années 1900 jusqu'en 2006 tandis que des hausses dans la concentration industrielle et la productivité des firmes ont été signalées durant la même période dans l'industrie agroalimentaire.

JEL classifcation: D24; L11; L25; L66

Keywords: Input price; Downstream industry; Entry/exit; Industrial concentration; Firm heterogeneity. 


\section{Introduction}

Agricultural prices have been falling between the early 1900s until recently (2006) in different countries while, over the same period, there is a trend towards higher concentration in the agrifood industry with an increase in average productivity (Cotterill 1999; Gardner, 1992; Ollinger et al., 2005). For example, in the US, whether material inputs alone, which include primary agricultural goods, account for almost all of the growth and of the increase in competitiveness in agrifood sectors, it appears that all firms did not gain to the same extent, as the concentration in market shares continued to increase (see Gopinath et al. 1996 and 2004). Similarly, in France, the relative prices of agricultural commodities have declined for the period 1973-2004 (Butault, 2008) whereas the market shares of the largest agrifood firms have increased (Blanchard et al., 2010) ${ }^{1}$

In this paper, we set up a simple model that explains the relation between low input price, high exit rates and industrial concentration. More precisely, we argue that falling input prices force low productive firms to exit and induces expansion of more efficient incumbents at the expense of less productive producers. Our model helps reconcile some well-established empirical results regarding the food processing industry, which may seem to be contradictory. Indeed, because the agrifood firms use intensively agricultural goods as inputs and are sensitive to agricultural prices (Gopinath, 1996; Paul and MacDonald, 2003), we might expect that a decline in relative prices of agricultural commodities reduces the production costs of food processing firms allowing them to increase their sales or inducing the entry of new firms. However, the effects of input prices deserve much more attention. Indeed, one the one hand, similar to the other manufacturing sectors, food processing firms exhibit heterogeneity in terms of productivity, plant size, and market share (Gopinath et al., 1996 and 2004; Blanchard et al., 2010). On the other hand, food firms operate under imperfect competition and sell differentiated products (Sexton and Lavoie, 2001; McCorriston, 2002). In addition, because characteristics of firms can affect the way firms respond to changes in input prices, each food processing firm can adjust its output price differently. Then, a reallocation of market shares across firms can occur in response to a change in agricultural prices. In other words, a priori we do not know whether input price cuts favor the entry or the exit of firms and the direction of the reallocation of market share across firms.

\footnotetext{
${ }^{1}$ This negative relationship between input prices and exit rates is not specific to the food sector. Recent papers reveal that in sectors where the prices of machinery inputs fall faster, the firms using those machines experience higher rates of exit (Jovanovic and Tse, 2011; Samaniego, 2011).
} 
The literature is rather silent on the impact of the level of input prices on structural change within downstream industries. There are many studies on industry evolution with heterogeneous plants or firms (Jovanovic, 1982; Hopenhayn, 1992; Ericson and Pakes, 1995; Melitz, 2003). A robust finding is aggregate productivity increases through either market share shifts to more efficient firms or exit of low productivity producers. Recent literature in industrial organization provided evidence for marked heterogeneity in firms' behavior, even in narrowly defined industries or markets (see Bartelsman et al, 2002). The exit of firms is a common phenomenon. For example, Bartelsman et al. (2002) reported that the firm turnover rate in OECD countries is non negligible, around 20\% (for example $23 \%$ in the United States). In the food industry, Blanchard et al. (2010) show that the turnover rate reaches a value between $11.5 \%$ and $15.5 \%$. The studies on firm demography and concentration in particular markets mainly focuses on determinants such as sunk costs, the degree of competition in the sector, the age of a firm, its productivity level or its status (a domestic, exporter or multinational firm). The impact of input prices on market structure has not received much attention.

We develop a general equilibrium model where firms are heterogeneously impacted by lower input prices coming from technical progress or trade liberalization in the input sector. We consider that firms in the downstream industry differ in labor productivity and produce a differentiated product under monopolistic competition, like in Melitz (2003). However, unlike Melitz (2003), we consider firms use not only labor but also an intermediate good. In our approach, firms react differently to a change in the input price because labor and intermediate goods are not combined with a Cobb-Douglas technology ${ }^{2}$ Hence, we analyze the impact of input price on the endogenously determined output price, firm size, and number of firms in the domestic market.

We first consider a closed economy. We show that, because output price elasticity to a change in input price increases with labor productivity, lower input price induces a reallocation of market shares from low productive firms to high productive ones, reinforcing the concentration in the industry. Because of fixed entry costs, less productive firms exit from market when input prices decline. Hence, our framework show how lower input prices raise aggregate productivity through market share shifts to more efficient producers and exit of low productivity firms. In addition, our analysis reveals that consumers gain always from lower input prices, even though these encourage concentration in the downstream industry. Indeed, lower input prices allow for better allocation of resources across firms.

\footnotetext{
${ }^{2}$ This point will be discussed in the next section.
} 
Further, we introduce a second country in order to investigate how input trade liberalization affects domestic firms. Whether lower agricultural prices were mainly due to productivity gains in the agricultural sector, recent trade reforms have also induced lower agricultural prices in the main agricultural producing countries. In order to comply with the Uruguay Round Agreement on Agriculture, several reforms of the European agricultural policies were undertaken in both the agricultural and the agrifood sector. One of the aims of this agreement was to reduce agricultural and agrifood tariffs on a simple average basis by $36 \%$, with a minimum reduction of $15 \%$ per tariff line to be implemented in equal annual installments (two-thirds of these rates for developing countries, and no reduction for the least-developed countries).

Recent literature on heterogeneous firms explains the exit and the reallocation process by the global trade liberalization of output sectors (see the seminal paper by Melitz, 2003). A symmetric fall in trade barriers leads to an increase in market shares for more productive firms through their exports, and favors the exit of less productive firms from the domestic market due to fiercer competition from new imported varieties. However, this literature focuses on the effects of output tariffs and not on input tariffs. Yet, input trade liberalization seems to have stronger impact on domestic firms. For example, Amiti and Konings (2007) showed that trade liberalization can explain the increase in productivity in the final good market, and that input trade liberalization explains this increase twice as much as output trade liberalization. Several studies have shown that importing inputs increases productivity (Halpern et al., 2009; Goldberg et al., 2009), and favors the introduction of new varieties of final goods (Goldberg et al., 2010). However, in these studies, the impact of input trade liberalization, or of imported inputs, is the same for all firms and does not depend on the heterogeneity of firms. Yet, empirical evidence shows that more productive firms are more likely to enter the import market than in the same industry (Kashara and Lapham, 2007; Kugler and Verhoogen, 2009). For exampe, Chevassus-Lozza et al. (2012) reveal that, under certain conditions, agricultural tariff liberalization reduces the probability of exporting and increases the export sales of high productive firms at the expense of low productive firms in the food sector. However, they consider that the mass of firms in the domestic market is exogenous and that all firms source to the same price because of a complete pass-through of tariff reduction on domestic prices. In our approach, we focus on the effects of lower input price on domestic markets by introducing an endogenous mass of firms able to produce and able to source inputs in foreign countries.

We analyze different configurations. First, we consider free input trade. Further, we 
introduce a variable import cost. Lastly, we assume the existence a fixed import cost leading to a selection among firms able to import profitably. Regardless of the structure of import costs, it appears input trade openness increases the probability of exiting the domestic market in the input importing country. In addition, a move from no trade to input trade with fixed import costs leads to higher profits for more productive firms at the expense of surviving non-importing firms and less productive importing firms. Hence, input trade openness may force some firms to cease operations and may hurt the less productive surviving firms. Whatever import costs structure, only the biggest firms gain from input trade liberalization.

Our results show also falling fixed import cost has ambiguous effects on downstream industry. Indeed, starting from high values, lower fixed import costs raise the probability of importing, as expected, but increase the probability of exiting the domestic market in the input importing country. Because an increasing share of firms can purchase cheaper inputs, there is a reallocation of demand from non importing firms to importing firms. In other words, by increasing the share of firms able to import, the operating profits of non-importing firms diminish substantially when fixed import costs shrink.

In the next section, we consider the impact of input prices in a closed economy. In Section 3, the effects of input trade liberalization are analyzed. We conclude in the last section.

\section{Closed economy}

\subsection{Preferences, technology and prices}

We first consider a framework with one country denoted by $h$ and three goods: a numeraire $(N)$, an intermediate good $(I)$ and a final differentiated good $(Y)$. We assume that the numeraire is produced under perfect competition with constant returns to scale by using a single input labor. One unit of labor is required to produce one unit of $N$ so that the wage rate in the economy is equal to 1 . Labor is assumed to be supplied inelastically and its amount available in the economy is given by $L$. The units of labor are divided between the numeraire $L_{h}^{N}$, the intermediate $L_{h}^{I}$, and the final sector $L_{h}^{Y}$, with

$$
L=L_{h}^{N}+L_{h}^{A}+L_{h}^{Y}
$$

Consumption. The preferences of the representative consumer living in country $h$ are given by a Cobb-Douglas utility function $U_{h}$ between the numeraire $N_{h}$ and the differen- 
tiated good $Y_{h}$ in which the utility resulting from the consumption of the differentiated good is given by a CES sub-utility function:

$$
U_{h}=N_{h}^{1-\beta} Y_{h}^{\beta} \text { with } Y_{h} \equiv\left[\int_{\omega \in \Omega_{h}} y_{h}(\omega)^{\rho} d \omega\right]^{1 / \rho}
$$

where $0<\rho<1$ and $0<\beta<1$ whereas $\Omega_{h}$ represents the set of varieties available in the country. Note that $\Omega_{h}$ is endogenously determined. Varieties are substitutes and the elasticity of substitution between any two varieties is given by $\varepsilon=1 /(1-\rho)>1$. The budget constraint of the representative consumer is given by $L=N_{h}+\int_{\omega \in \Omega_{h}} p_{h}(\omega) y_{h}(\omega) \mathrm{d} \omega$ where $p_{h}(\omega)$ (resp., $y_{h}(\omega)$ ) is the price (resp., quantity) of the variety $\omega$ consumed in country $h$. Maximization of (1) under the budget constraint leads to a constant share of expenditure dedicated to the differentiated good equal to $\beta$ and to the optimal consumption of each variety $y_{h}(\omega)$ :

$$
y_{h}(\omega)=\beta L P_{h}^{\varepsilon-1} p_{h}(\omega)^{-\varepsilon}
$$

where $P_{h}$ is the price index associated with the differentiated good given by

$$
P_{h}=\left[\int_{\omega \in \Omega_{h}} p_{h}(\omega)^{1-\varepsilon} \mathrm{d} \omega\right]^{\frac{1}{1-\varepsilon}}
$$

whereas the demand for the numeraire in country $h$ is expressed as follows:

$$
N_{h}=(1-\beta) L
$$

Hence, whether the total market size is fixed, the market share of each variety is endogenous. It depends on its own price and on the price index.$^{3}$

The intermediate good sector. The intermediate good sector (say the agricultural sector) is perfectly competitive. Firms use the same technology and produce a homogeneous good using a single input, labor. The aggregate profit in the intermediate sector in country $h$ is given by $\pi_{h}^{I}=z_{h} I_{h}-L_{h}^{I}$ where $z_{h}$ is the intermediate good price in country $h$ and $I_{h}$ is the quantity of intermediate goods purchased by downstream firms. At equilibrium, there is no pure profits and we have

$$
z_{h} I_{h}=L_{h}^{I}
$$

The final good sector. There is a continuum of downstream firms producing a single differentiated variety $\omega$. To produce for their domestic market, firms have to pay a sunk

\footnotetext{
${ }^{3}$ It should be interesting to determine in what extent our main results remain valid when total market size can vary substantially when prices change.
} 
$\operatorname{cost} \mathrm{f}_{e}$ to enter the market, and incur a fixed production cost $\mathrm{f}_{d}$. All fixed costs are in terms of labor units. The production of variety $\omega$ requires two production factors, labor and intermediate goods. Each firm uses $\alpha$ units of the intermediate good and $1 / \varphi$ units of labor to produce one unit of final good.

We consider that labor productivity differs across firms, as in Melitz (2003), while the requirement in the intermediate good sector to produce one unit of final good is exogenous and identical for all firms. Hence, a firm can be more efficient, and use a less labor-intensive technology to produce its variety. In addition, it appears that the ratio of intermediate consumption to labor cost, given by $\varphi z_{h} \alpha$, is not constant across firms and increases with labor productivity, which fits well with empirical evidence (see Chevassus-Lozza et al., 2012).

Because firms vary with respect to their labor productivity $\varphi$, we refer to a given firm by its labor productivity. The marginal cost of production of a firm in country $h$ is given by $z_{h} \alpha+1 / \varphi$. In other words, the marginal cost differs across firms and decreases with labor productivity. Note that higher input prices reduce the difference in marginal costs across firms. Under monopolistic competition, each firm faces a residual demand curve with constant elasticity $\varepsilon$ leading to the pricing rule:

$$
p_{h}(\varphi)=\frac{\varepsilon\left(z_{h} \alpha+1 / \varphi\right)}{\varepsilon-1}
$$

where $\varepsilon /(\varepsilon-1)$ is the markup.

Let $r_{h}=p_{h} y_{h}$ be the sales so that the profit of a firm $\varphi$ producing in country $h$ is given by

$$
\pi_{h}(\varphi)=\frac{r_{h}(\varphi)}{\varepsilon}-\mathrm{f}_{d}
$$

where

$$
r_{h}(\varphi)=\beta L\left(\frac{\varepsilon}{\varepsilon-1}\right)^{1-\varepsilon}\left(\frac{P_{h}}{z_{h} \alpha+1 / \varphi}\right)^{\varepsilon-1} .
$$

by introducing (5) and (2) in $r_{h}$. Hence, $r_{h}\left(\varphi_{1}\right) / r_{h}\left(\varphi_{2}\right)>1$ when $\varphi_{1}>\varphi_{2}$ but decreases with $z_{h}$. In other words,

Lemma 1. At any given mass of firms, lower input prices increases the gap in operating profits among firms.

\subsection{Firms' entry in and exit from the final good sector.}

We adopt the entry/exit process developed in Melitz (2003). To enter the market, final sector firms have to pay a sunk entry cost equal to $\mathrm{f}_{e}$ units of labor. However, firms do not 
know their productivity prior to starting production. The labor productivity level $\varphi$ of each firm is randomly drawn from a common distribution $g(\varphi)$ where $g(\varphi)$ is positive over $(0, \infty)$ and has a continuous cumulative function $G(\varphi)$. Firms then decide to produce or not. If a firm does produce, a productivity shock may force it to exit with a probability of $\delta$. This probability is common to each producing firm and is constant over time. As the productivity of a firm remains constant over time, its equilibrium profit is also constant, until a negative shock forces it to exit. The value function of a firm is given by their discounted profit flows:

$$
v_{h}(\varphi)=\max \left\{0, \sum_{t=0}^{\infty}(1-\delta)^{t} \pi_{h}(\varphi)\right\}=\max \left\{0, \frac{\pi_{h}(\varphi)}{\delta}\right\}
$$

If the labor productivity of a firm is too low, its discounted profit flow will be negative, and, in turn, the firm will fail to enter the market. Thus, there is a threshold of labor productivity $\bar{\varphi}_{h}$ above which a firm can enter the domestic market and expect a positive profit. In other words, the productivity cutoff $\bar{\varphi}_{h}$, defined as the minimum value of labor productivity, leads to a non-negative firm value such as

$$
\bar{\varphi}_{h}=\inf \left\{\varphi: v_{h}\left(\varphi, z_{h}\right) \geq 0\right\}=\inf \left\{\varphi: \pi_{h}\left(\varphi, z_{h}\right) \geq 0\right\}
$$

Hence, equilibrium is characterized by a mass $M_{h}$ of firms and a distribution $\mu_{h}(\varphi)$ if labor productivity over a subset of $\left[0, \infty\left[\right.\right.$ where $\mu_{h}(\varphi)$ is the conditional distribution of $g(\varphi)$ on $\left[\bar{\varphi}_{h}, \infty[\right.$ with

$$
\mu_{h}(\varphi)=\left\{\begin{array}{cl}
\frac{g(\varphi)}{1-G\left(\bar{\varphi}_{h}\right)} & \text { if } \varphi \geq \bar{\varphi}_{h} \\
0 & \text { if } \varphi<\bar{\varphi}_{h}
\end{array}\right.
$$

where $1-G\left(\bar{\varphi}_{h}\right)$ is the ex-ante probability of successful entry in country $h$.

Hence, the expected profit of a firm prior to entering the market is given by $\theta_{h} \tilde{\pi}_{h}$ with

$$
\tilde{\pi}_{h}=\int_{0}^{\infty} \pi_{h}(\varphi) \mu_{h}(\varphi) \mathrm{d} \varphi
$$

A firm enters the market as long as $\left[1-G\left(\bar{\varphi}_{h}\right)\right] \tilde{\pi}_{h} / \delta-\mathrm{f}_{e} \geq 0$ (free entry condition). If a firm decides to enter, it will finally serve the domestic market if and only if $\pi_{h}(\varphi) \geq 0$ or equivalently $\varphi \geq \bar{\varphi}_{h}$.

Note that, because $\partial \pi_{h} / \partial \varphi>0$, this approach induces that entrants are smaller or have a lower productivity than average incumbents and the exiters are smaller or have a lower productivity than incumbents, in accordance with empirical evidence (Foster et al., 2008). 


\subsection{The impact of input prices on entry in/exit from the do- mestic market}

At equilibrium, we have $\left[1-G\left(\bar{\varphi}_{h}\right)\right] \tilde{\pi}_{h}=\delta \mathrm{f}_{e}$ and $\pi_{h}\left(\bar{\varphi}_{h}\right)=0$. By using the latter condition as well as (6), we have $r_{h}\left(\bar{\varphi}_{h}\right)=\varepsilon f_{d}$. As a result, as shown in Appendix A.1, $\tilde{\pi}_{h}$ can be rewritten as a function of $\bar{\varphi}_{h}$ :

$$
\tilde{\pi}_{h}=\frac{\mathrm{f}_{d}}{1-G\left(\bar{\varphi}_{h}\right)}\left(\frac{1}{\bar{\varphi}_{h}}+z_{h} \alpha\right)^{\varepsilon-1} \int_{\bar{\varphi}_{h}}^{\infty}\left(\frac{1}{\varphi}+z_{h} \alpha\right)^{1-\varepsilon} g(\varphi) \mathrm{d} \varphi-\mathrm{f}_{d}
$$

We show in Appendix A.2 that $\bar{\varphi}_{h}$ exists, is positive and unique and in Appendix A.3 that, knowing the free entry condition,

$$
\frac{\mathrm{d} \bar{\varphi}_{h}}{\mathrm{~d} z_{h}}=\frac{\mathrm{d} \tilde{\pi}_{h}}{\mathrm{~d} z_{h}} \frac{\left[1-G\left(\bar{\varphi}_{h}\right)\right]^{2}}{\delta \mathrm{f}_{e} g\left(\bar{\varphi}_{h}\right)}<0 .
$$

Proposition 1 Lower input prices reduce the probability of entering the domestic market and increase average productivity.

This result arises from the fact that the share of intermediate products in total costs $\left(\alpha_{h} z /\left(\alpha z_{h}+1 / \varphi\right)\right)$ increases with an increase in labor productivity. Indeed, the elasticity of output price to a change in input price is given by

$$
\epsilon_{p_{h}, z_{h}} \equiv \frac{\partial p_{h}(\varphi)}{\partial z_{h}} \frac{z_{h}}{p_{h}(\varphi)}=\frac{1}{1+\frac{1}{\alpha z_{h} \varphi}}
$$

where $\partial \epsilon_{p_{h}, z_{h}} / \partial z_{h}>0$ and $\partial^{2} \epsilon_{p_{h}, z_{h}} / \partial z_{h} \partial \varphi>0$. In other words, a fall in the price of the intermediate good leads to a higher decrease in the price of the final product produced by high productivity firms which, in turn, leads to reallocation of demand from low productivity firms to high productivity firms.

It is worth stressing that this property of $\epsilon_{p_{h}, z_{h}}$ holds for different technologies, except Cobb-Douglass technology. For example, if we consider labor and material input are combined according to the CES aggregator, we obtain the same result. With a CobbDouglas technology, the output price elasticity to a change in intermediate product price does not differ among firms. However, a Cobb-Douglas function does not fit the data well, as shown convincingly in Raval (2011). Within a 4 digit industry, the author shows that US manufacturing plants have large differences in their labor shares while Cobb-Douglas production function implies that firm productivity does not affect the relative proportions of factors that are used by the firm. In addition, his study reveals that firms with higher value added have lower labor shares. Chevassus-Lozza et al. (2012) confirm these findings with data on French agri-food firms. 
Further, we could also consider that firms are heterogeneous in the use of the intermediate product. In other words, we can also assume that each firm draws $\alpha$ randomly from a common distribution. Chevassus-Lozza et al. (2012) show if the ranking of firms with respect to labor productivity corresponds to the ranking of firms according to the intermediate input productivity, a sufficient condition for $\partial \epsilon_{p_{h}, z_{h}} / \partial z_{h}>0$ is that heterogeneity in labor productivity be higher than heterogeneity in intermediate input productivity.

\subsection{Input prices, size of the final sector, and welfare}

At stationary equilibrium, all variables remain constant. The mass of new entrants $M_{h}^{e}$ must successfully replace the mass of firms that leave the market so that $\left[1-G\left(\bar{\varphi}_{h}\right)\right] M_{h}^{e}=$ $\delta M_{h}$ where $M_{h}$ is the mass of firms producing the differentiated product. Note that the mass of firms corresponds to the mass of varieties available to consumers. Hence, when there is a new entrant, it supplies a new variety. $\left.\right|^{4}$

Note that $M_{h}=R_{h} / \tilde{r}_{h}$ where $R_{h}$ (resp., $\tilde{r}_{h}$ ) is the total (resp., average) income of the final sector firms in country $h$. Knowing $R_{h}=\beta L$ and

$$
\tilde{\pi}_{h}=\frac{\tilde{r}_{h}}{\varepsilon}-\mathrm{f}_{d}
$$

we have

$$
M_{h}=\frac{\beta L}{\varepsilon\left(\tilde{\pi}_{h}+\mathrm{f}_{d}\right)} .
$$

As a result, the impact of input prices on the mass of firms is given by

$$
\frac{\mathrm{d} M_{h}}{\mathrm{~d} z_{h}}=\frac{-M_{h}}{\tilde{\pi}_{h}+\mathrm{f}_{d}}\left(\frac{\partial \tilde{\pi}_{h}}{\partial z_{h}}+\frac{\partial \tilde{\pi}_{h}}{\partial \varphi} \frac{\partial \bar{\varphi}_{h}}{\partial z_{h}}\right)>0
$$

where $\partial \tilde{\pi}_{h} / \partial z_{h}<0$ and $\partial \bar{\varphi}_{h} / \partial z_{h}<0$, as shown in Appendix A.3. Thus, a fall in the price of the intermediate good reduces the mass of firms and thus the number of varieties. Indeed, a lower input price raises the threshold value of labor productivity above which a firm can profitably produce and increases the average sales. As a consequence, because the aggregate expenditures for the final good is not affected by a change in input prices, fewer firms successfully enter the market when input prices shrink.

Using the utility function $(1)$, indirect utility is given by $V_{h}=P_{h}^{-\beta}$. Because $r_{h}\left(\bar{\varphi}_{h}\right)=$ $\varepsilon \mathrm{f}_{d}$ and $r_{h}(\varphi)=\beta L P_{h}^{\varepsilon-1} p_{h}^{1-\varepsilon}$, we can write

$$
P_{h}=\left(\frac{\varepsilon f_{d}}{\beta L}\right)^{\frac{1}{\varepsilon-1}} p_{h}\left(\bar{\varphi}_{h}\right)
$$

\footnotetext{
${ }^{4}$ According to MacDonald (1986) a significant share of new products arises from new entrants.
} 
Some standard calculations reveal that

$$
\frac{\mathrm{d} p_{h}\left(\bar{\varphi}_{h}\right)}{\mathrm{d} z_{h}}=\alpha+\frac{\partial p(\varphi)}{\partial \varphi} \frac{\partial \bar{\varphi}_{h}}{\partial z}=\alpha-\frac{1}{\bar{\varphi}_{h}^{2}} \frac{\partial \bar{\varphi}_{h}}{\partial z_{h}}>0
$$

so that a fall in intermediate good price decreases the price index $\left(\mathrm{d} P_{h} / \mathrm{d} z_{h}>0\right)$ and, in turn, increases consumer welfare $\left(\mathrm{d} V_{h} / \mathrm{d} z_{h}<0\right)$. As a result, the positive effect associated with falling prices paid by end consumers is greater than the negative effect related to the decrease in the number of varieties available for consumers.

Proposition 2 A fall in input prices increases consumer welfare even if the mass of varieties available to consumers decreases.

The effects of input price on the reallocation of resources between the final and the intermediate sectors in unclear 5 The mass of labor used in the final and intermediate is given by $L_{h}^{I}+L_{h}^{F}=\beta L$. Because the total expenditures for the final good remains constant, a fall in the price of the intermediate good increases the total demand for the differentiated good because the index price declines and, in turn, the demand for the intermediate product increases. In addition, as less productive firms exit the market with lower input prices, average productivity increases and, in turn, aggregate production in the final good sector can increase using the same amount of labor. As a result, the effect of input price on the allocation of labor between sector is ambiguous. We know that the mass of labor dedicated to the production of the final good is given by

$$
L p_{h}=\beta L-\left(M_{h} \mathrm{f}_{d}+M_{h}^{e} \mathrm{f}_{e}\right)-L_{h}^{I}
$$

Because, $M_{h} \mathrm{f}_{d}+M_{h}^{e} \mathrm{f}_{e}=M_{h}\left(\mathrm{f}_{d}+\tilde{\pi}_{i}\right)=\beta L / \varepsilon$ at the equilibrium, we get $L p_{h}=\rho \beta L-L_{h}^{I}$. Knowing technology used in the final sector, we can write that $I_{h}=\alpha \widetilde{\varphi}_{h} L p_{h}$ where $\widetilde{\varphi}_{h}$ is the average labor productivity. In addition, knowing that $z_{h} I_{h}=L_{h}^{I}$, we have $L_{h}^{I}=z_{h} \alpha \widetilde{\varphi}_{h} L p_{h}$ so that

$$
L p_{h}=\frac{\rho \beta L}{z_{h} \alpha \widetilde{\varphi}_{h}}
$$

Clearly, the effect of input prices is ambiguous because the average labor productivity increases when input prices fall. However, if the intermediate sector produces under constant returns, it is straightforward to check that the size of the final sector in terms

\footnotetext{
${ }^{5} \mathrm{~A}$ change in input prices does not impact the amount of labor required to produce the numéraire. Indeed, we have $L_{h}^{N}=(1-\beta) L$.
} 
of jobs increases when inputs are cheaper. Indeed, if $I_{h}=\xi L_{h}^{I}$ with $\xi>0$, we have $L_{h}^{I}=\alpha \widetilde{\varphi}_{h} L p_{h} / \xi$. Knowing $L p_{h}=\rho \beta L-L_{h}^{I}$, we get

$$
L p_{h}=\frac{\rho \beta L}{1+\alpha \widetilde{\varphi}_{h} / \xi}
$$

Hence, when the production of the intermediate product is characterized by constant returns, lower input prices and higher productivity in this sector increases the number of jobs in the downstream sector. To sum up,

Proposition 3 When the intermediate sector operates under constant returns, falling input prices induces a reallocation of labor from the intermediate sector to the more productive firms in the final sector.

A final remark in this section is needed. We discuss whether our results are robust if we consider foreign competition. We have shown that cheaper input favors the exit from the market of less productive firms and benefits more productive firms. In our framework, there is no international competition on the output market. In international trade models with heterogeneous firms, trade openness leads to fiercer competition from foreign firms, and all firms selling on the domestic market are affected by the entry of new competitors. It is showed that output trade liberalization leads to the exit of smaller and less productive firms (Melitz, 2003). Hence, if we consider international competition in our framework, the effects of lower input prices would be stronger. Openness to output trade or lower input prices increase the exit from domestic markets of firms located in the input importing country.

\section{International trade in intermediate goods}

\subsection{Preferences, technology and market structure}

We now consider a world with two countries denoted by $h$ and $f$ (the European Union and the United States, for example). The two countries host the three sectors described above. The preferences of representative consumers living in both countries are given by the same Cobb-Douglas utility function between the numeraire and the differentiated good, leading to the same demand for each variety as presented in section 2 . The numeraire is produced in both countries and is internationally traded without any cost. Hence, the wage rate is equal to one in each country. In both countries, the intermediate good firms produce the same homogeneous intermediate good using a single input, labor. 
The countries differ only in the input price. The reasons explaining the international difference in input prices does not matter (the difference can be due to differences in productivity in the intermediate sector or to public intervention through subsidy/tax for example). Without loss of generality, we assume that the intermediate product is more expensive in country $h\left(z_{h}>z_{f}\right)$. If countries have the same price, there is no input trade across countries and they have the same characteristics.

Assume first that input prices are different among countries but there is no input trade. Given the results presented in the previous section, when $z_{h}>z_{f}$ and if firms produce using exclusively local inputs, the domestic labor productivity threshold is higher in country $f\left(\bar{\varphi}_{f}>\bar{\varphi}_{h}\right)$. In other words, the probability of entering the domestic market is higher in the country with the higher input price, namely country $h$. In addition, the price index is higher in country $h$, so consumer welfare is lower than in country $f$ even if the number of varieties is higher. In future comparisons, the threshold values of labor productivity and endogenous variables with asymmetric countries without input trade are listed without a superscript.

Consider now firms can source the intermediate product in the foreign country. Because $z_{h}>z_{f}$, firms located in country $h$ are prompted to import the intermediate product from country $f$. Importing firms incur the following import costs

$$
\tau_{I} z_{f} \alpha y\left(\varphi, z_{f}\right)+\mathrm{f}_{M}
$$

where $\mathrm{f}_{M} \geq 0$ is a fixed import cost (paid in terms of labor units) and $\tau_{I} \geq 1$ is the Samuelson's iceberg transport cost (only a fraction of the good shipped reaches its destination). Firms that do not import incur the following cost $z_{h} \alpha y\left(\varphi, z_{h}\right)$ for using their intermediate good as in the previous section. Because the intermediate good is homogenous, firms producing in country $f$ do not import inputs. In other words, the input trade (if any) is unilateral from country $f$ to country $h$.

If a firm imports, its marginal cost (and thus its output price up to $\varepsilon /(\varepsilon-1)$ ) is given by $\tau_{I} z_{f}+1 / \varphi$. Note that the decision to import cannot be determined by comparing $z_{h} y(\varphi)$ and $\tau_{I} z_{f} y(\varphi)+\mathrm{f}_{M}$ because $y(\varphi)$ depends on the import status of the firm for the same level of labor productivity. For a given level of labor productivity, different input prices result in different output prices and, in turn, in different sales.

In what follows, we first investigate the effects of freer input trade when there is no fixed import costs $\left(\tau_{I} \geq 1\right.$ and $\left.f_{M}=0\right)$. Then, we consider the effects of input trade liberalization with positive import fixed $\operatorname{cost}\left(\mathrm{f}_{M}>0\right)$. Note that $\mathrm{f}_{M} \rightarrow \infty$ is equivalent to the configuration where there is no input trade. 


\subsection{Intermediate good price and entry/exit with no fixed import $\operatorname{cost}\left(\mathbf{f}_{M}=0\right)$}

In this subsection, we assume that all firms can import intermediate goods without any fixed costs so that all firms producing in country $h$ import the intermediate product and firms producing in the foreign country purchase their intermediate goods locally.

Free input trade. We start with the simplest case where $\tau_{I}=1$. In other words, input trade is costless. Threshold values of labor productivity and endogenous variables with free input trade are denoted with superscript $F$. Because the price of the intermediate good is higher in country $h\left(z_{h}>z_{f}\right)$, the openness to trade in the intermediate good sector leads to imports of this good from country $f$ to country $h$. We show in Appendix B that the total value of imports (resp., exports) of intermediate goods equals the total value of exports (resp., imports) of numeraire, implying that in both countries, the amount of labor available to produce the final good is the same. Further, knowing that $r_{i}\left(\bar{\varphi}_{i}^{F}\right)=\varepsilon f_{d}$ in both countries at the equilibrium and the expression of $r_{i}\left(\bar{\varphi}_{i}^{F}\right)$, we can write

$$
\frac{P_{h}^{F}}{P_{f}^{F}}=\frac{p_{f}\left(\bar{\varphi}_{h}^{F}\right)}{p_{h}\left(\bar{\varphi}_{h}^{F}\right)}=1
$$

so that $p_{h}\left(\bar{\varphi}_{h}^{F}\right)=p_{f}\left(\bar{\varphi}_{f}^{F}\right)=p_{f}\left(\bar{\varphi}_{f}\right)<p_{h}\left(\bar{\varphi}_{h}\right)$ and, thus, $\bar{\varphi}_{h}^{F}=\bar{\varphi}_{f}^{F}$. Indeed, as imports of intermediate goods do not involve additional costs, firms in both countries purchase intermediate goods at the same price and the marginal costs are the same in the two countries for the same level of labor productivity. Given that the mass of firms and the demand is the same in both countries, the structure of the final good sector is also the same in both countries.

Without input trade, the probability of entering the domestic market is higher in country $h$. A move from a situation with no input trade to free input trade triggers a fall in marginal costs in country $h$ as well as in the price index in this country and, in turn, decreases the probability of entering in the importing country (see (13)). In the exporting country (country $f$ ), the openness to trade in the intermediate good sector does not affect final good firms; the amount of labor available, the demand and the production costs remain unchanged. Hence, we have:

$$
\bar{\varphi}_{h}^{F}=\bar{\varphi}_{f}^{F}=\bar{\varphi}_{f}>\bar{\varphi}_{h}
$$

Remember that without trade in the intermediate good, the price index is higher in country $h\left(P_{f}<P_{h}\right)$, as the probability of entering the domestic market $\left(\bar{\varphi}_{h}<\bar{\varphi}_{f}\right)$. 
Hence, we have

$$
P_{h}^{F}=P_{f}^{F}=P_{f}<P_{h}
$$

In other words, a shift to free trade in intermediate products leads to a convergence of the price index between country and improves consumer welfare in the input importing country.

Positive variable import costs. When input trade involves a variable cost $\tau_{I}>1$, firms located in country $h$ import if and only if $\tau_{I}<z_{h} / z_{f}$. Threshold values of labor productivity and endogenous variables with variable input trade costs are now denoted with superscript $V$. As when $\tau_{I}=1$, total exports of numeraire from country $h$ are the same as total imports of intermediate goods from country $f$. Thus, the amount of labor available to produce the final good is the same in both countries and the threshold values are the same. Thus, except for exchanges of intermediate goods and numeraire, the configuration is similar to the case with two asymmetric countries without trade. However, the marginal cost of firms in country $h$ decreases as long as $\tau_{I}<z_{h} / z_{f}$.

Because the fall in marginal costs in the input importing country is lower than under free input trade, the impact on price indexes is weaker. Hence, we have

$$
\bar{\varphi}_{h}<\bar{\varphi}_{h}^{V}<\bar{\varphi}_{h}^{F} \quad \text { and } \quad \bar{\varphi}_{f}=\bar{\varphi}_{f}^{V}=\bar{\varphi}_{f}^{F}
$$

As expected, the fall in prices of intermediate goods purchased by firms in country $h$ leads to lower price index in this country, and to a decrease in the probability of entering the domestic market. In addition, a fall in $\tau_{I}$ leads to a convergence in the threshold values of labor productivity in both countries.

To sum up

Proposition 4 A move from no input trade to free input trade decreases the probability of entering the domestic market, increases average productivity, and does not increase the number of jobs in the final sector.

\footnotetext{
${ }^{6}$ It is worth stressing that the effect of a switch from no input trade to free input trade has the same effects than a unilateral fall in the price of the intermediate product in the input importing country, except for international trade structure which leads to unilateral trade in numeraire and in intermediate goods.
} 


\subsection{Intermediate good prices and entry/exit with fixed input trade costs. $\left(\mathbf{f}_{M}>0\right)$}

We assume that $z_{f} \leq z_{h}, \tau_{I}=1$, and $\left.\mathrm{f}_{M}>0.7\right]$ Threshold values of labor productivity and endogenous variables with sunk input trade costs only are denoted with the superscript $S$. A firm decides to import the intermediate good as long as its profit is higher with the imported intermediate good than with the domestic one. Formally, a firm with a labor productivity $\varphi$ imports if and only if:

$$
\pi\left(\varphi, z_{f}\right)-\mathrm{f}_{M} \geq \pi\left(\varphi, z_{h}\right)
$$

Two opposite effects are at work. On the one hand, the existence of a fixed import cost encourages firms located in the high input price country to purchase the intermediate good in the domestic country even though its price is higher. On the other hand, each firm is prompted to import the intermediate product in order to reduce its marginal cost and, in turn, to increase its operating profits. Hence, a firm located in country $h$ sources its inputs in the foreign country if and only if the increase in operating profits is higher than fixed import cost.

Using (6) and $r_{h}\left(\bar{\varphi}_{h}\right)=\varepsilon f_{d},(22)$ can be rewritten as follows

$$
\left(\frac{\varphi}{\bar{\varphi}_{h}^{S}}\right)^{\varepsilon-1}\left[\frac{\left(z_{f} \alpha \varphi+1\right)^{1-\varepsilon}-\left(z_{h} \alpha \varphi+1\right)^{1-\varepsilon}}{\left(z_{h} \alpha \bar{\varphi}_{h}^{S}+1\right)^{1-\varepsilon}}\right] \mathrm{f}_{d} \geq \mathrm{f}_{M}
$$

because the left hand side of this inequality is non negative and increases from 0 to infinity when $\varphi$ moves from 0 to infinity (because $z_{f}<z_{h}$ ). Hence, above a positive limit value of labor productivity, firms import profitably. Let $\varphi_{M}$ be the labor productivity threshold for which a firm located in the input importing country is indifferent between importing and purchasing locally the intermediate product with

$$
\left(\frac{\varphi_{M}}{\bar{\varphi}_{h}^{S}}\right)^{\varepsilon-1}\left[\frac{\left(z_{f} \alpha \varphi_{M}+1\right)^{1-\varepsilon}-\left(z_{h} \alpha \varphi_{M}+1\right)^{1-\varepsilon}}{\left(z_{h} \alpha \bar{\varphi}_{h}^{S}+1\right)^{1-\varepsilon}}\right]=\frac{\mathrm{f}_{M}}{\mathrm{f}_{d}}
$$

Note that $\varphi_{M}$ increases with an increase in fixed import costs $\left(\mathrm{f}_{M}\right)$, so if fixed import costs are extremely high, no firm is able to import.

However, the decision of a firm to import has not only an impact on its own price but also on the price index. By changing the price index, the profits of non-importing firms vary. Remember that the operating profits are given by $P^{\varepsilon-1} p\left(\varphi, z_{i}\right)^{1-\varepsilon}$ (up to a

\footnotetext{
${ }^{7}$ If $\mathrm{f}_{M} \rightarrow \infty$, then all firms do not import the intermediate product. This case corresponds to the configuration where there is no input trade.
} 
constant) where $P$, the price index, is identical for all firms and $p\left(\varphi, z_{i}\right)$ is specific to each firm (according to its labor productivity and the input price). In other words, firms are indirectly connected through the price index. Hence, the effect of openness to trade on entry/exit and reallocation of market share depends on the share of firms choosing to import and, thus, on fixed import costs.

Fixed import costs and productivity cutoff. Note that when input trade is allowed with positive fixed import costs, productivity cutoffs are not necessarily identical in the two countries because profits differ across countries for a same level of labor productivity $\left(\bar{\varphi}_{h}^{S} \neq \bar{\varphi}_{f}^{S}=\bar{\varphi}_{f}\right)$. To analyze the effect of fixed import costs on exit/entry process, we have to consider two cases: (i) $\bar{\varphi}_{h}^{S}>\varphi_{M}$ (all firms producing import) and (ii) $\bar{\varphi}_{h}^{S}<\varphi_{M}$ (only a fraction of firms can import).

Consider first that fixed import costs are low enough $\left(\mathrm{f}_{M} \leq \mathrm{f}_{M}^{0}\right.$ with $\mathrm{f}_{M}^{0}$ such that $\left.\bar{\varphi}_{h}^{S}=\varphi_{M}\right)$ so that all firms producing in country $h$ import $\left(\bar{\varphi}_{h}^{S}>\varphi_{M}\right)$. Note that if $\mathrm{f}_{M}=0$, openness to input trade is equivalent to a shift to free input trade so that $\bar{\varphi}_{h}^{S}=\bar{\varphi}_{f}$. When $0<\mathrm{f}_{M} \leq \mathrm{f}_{M}^{0}$, the profits of firms in country $h$ are given by

$$
\pi_{h}^{S}=\frac{\beta L}{\varepsilon}\left[\frac{P_{h}}{p_{h}\left(\varphi, z_{f}\right)}\right]^{\varepsilon-1}-\mathrm{f}_{d}-\mathrm{f}_{M}
$$

while in country $f$ we still have

$$
\pi_{f}^{S}=\frac{\beta L}{\varepsilon}\left[\frac{P_{f}}{p_{f}\left(\varphi, z_{f}\right)}\right]^{\varepsilon-1}-\mathrm{f}_{d}
$$

Hence, openness to input trade reduces the probability of entering the domestic market. However, we have $\bar{\varphi}_{h}^{S}>\bar{\varphi}_{f}^{S}=\bar{\varphi}_{f}$. In other words, contrary to free input trade, there is no convergence in the probability of entering. Indeed, even if all firms import the intermediate good so that marginal costs are identical in both countries (for an identical level of labor productivity), firms producing in country $h$ must paid an additional fixed costs. Indeed, if $\bar{\varphi}_{h}^{S}=\bar{\varphi}_{f}$, then $\pi_{h}^{S}\left(\bar{\varphi}_{f}\right)<\pi_{f}^{S}\left(\bar{\varphi}_{f}\right)=0$ because $\mathrm{f}_{M}>0$. Hence, we must have $\bar{\varphi}_{h}^{S}>\bar{\varphi}_{f}^{S}=\bar{\varphi}_{f}$. In addition, contrary to the free trade case, the price index is different among countries so that operating profits vary with respect to the country even if firms have the same labor productivity and input price. More precisely, we have $P_{h}^{S}<P_{f}^{S}$ because the average productivity has to be higher in the importing country due to fixed import costs. In this case, the limit value of labor productivity above which a firm can profitably serve the market becomes higher in the importing country. In addition, a rise of $\mathrm{f}_{M}$ from 0 to $\mathrm{f}_{M}^{0}$ increases $\bar{\varphi}_{h}^{S}$. Indeed, the share of importing firms is unchanged 
while profits decline in the importing country. In other words, a large share of firms exits when trade is opened with fixed import costs.

Consider now the limit case where $\mathrm{f}_{M} \gtrsim \mathrm{f}_{M}^{0}$ such that only the less productive producing firm in country $h$ cannot import even if input trade can occur. In this case, openness to input trade results in lower price index in country $h$ because all existing firms in country $h$ can purchase a cheaper input in the foreign country (except the less productive firm) while the variety price of the less productive domestic firm does not vary, which undergoes a decrease in its market share and is forced to exit the market.

Consider now the other limit case where fixed import costs are extremely high so that only the most productive firm is able to import the intermediate good from country $f$. By this way, its marginal costs and output price decline. However, the index price decrease very slightly because the very large majority of firms does not import so that the price of many varieties is unchanged in country $h$ when only the most productive producer imports. In this case, freer input trade increases the market share of the most productive firms at the expense of the less productive firms. However, because the less productive firms do not paid an additional fixed cost and the price index decreases weakly in country $h$, the fall in profits of these less productive producers is low. In other words, openness to trade weakly increases the domestic labor productivity threshold when fixed import costs are high.

Hence, the effects of freer input trade on entry/exit depends on the share of firms able to import. Starting from high levels, lower fixed import costs increase the probability of exiting the market as long as $\varphi_{M}>\bar{\varphi}_{h}^{S}$ because the share of importing firms increases. Under these circumstances, the fall in the price index is relatively strong. Indeed, the higher the share of importing firms, the higher the decline in the price index. Because the price set by non importing firms remains unchanged, the fall in operating profits of the non importing firms is strong. As a consequence, the productivity cutoff for firms in country $h$ increases when fixed import costs shrink from high values as long as the number of importing firms increases. However, once $\varphi_{M}<\bar{\varphi}_{h}^{S}$, all firms import so that, the operating profits increase for all firms. Hence, reducing fixed import costs reduce the probability of exiting.

To summarize,

Proposition 5 Starting from high fixed import costs, the probability of exiting the domestic market in the input importing country increases with falling fixed import costs as long as $\mathrm{f}_{M}>\mathrm{f}_{M}^{0}$ and decreases once $\mathrm{f}_{M}<\mathrm{f}_{M}^{0}$. 
Input trade openness with fixed import costs: who gains and who loses? When some firms are not able to import (when $\varphi_{M}>\bar{\varphi}_{h}^{S}$ ), they lose market shares in favor to importing firms with input trade openness. Concerning the firms able to import the effects of input trade openness are unclear. The market share of some importing firms can also decline if a large share of surviving firms is able to import. Remember that the higher the share of importing firms, the higher the fall in the price index. Then, as the fall in the output price is lower for less productive importing firms, the decrease in the output price of some low productivity importing firms may be lower than the fall in the price index (so that $P_{h} / p_{h}$ may decrease for some firms). Consequently, the less productive importing firms can lose market shares when fixed import costs fall with openness to trade. In other words, when fixed import costs are low enough (but higher than $\mathrm{f}_{M}^{0}$ ), reallocation of sales occurs across importing firms. Hence, an increase in fixed import costs reduces reallocation between importing firms but promotes the reallocation from non importing firms to importing firms. When fixed import costs are high enough, reallocation between importing firms no longer occurs, and all importing firms gain from input trade openness at the expense of non-importing firms.

\section{Conclusion}

We developed a theoretical model to highlight the impact of input market liberalization on entry/exit, reallocation of market shares among firms and average productivity. Only the more productive firms benefit from lower input price, even if all firms can decrease their marginal costs. The gains from input market liberalization is even more concentrated on a lower fraction of firms if some firms cannot source input in the market supplying cheaper input due to fixed import costs. In addition, because openness to input trade also affects market structure in the final good sector, even importing firms may be affected negatively even though they have access to cheaper inputs. As some firms are more impacted than others depending on labor productivity, relative prices of varieties are modified. We have shown that more productive incumbents are able to reduce their prices to a greater extent than less productive firms, because the latter use relatively more inputs. This leads to reallocation of market shares from low productivity firms to high productivity firms. This forces less productive firms to exit the domestic market, increases the concentration of market shares and induces a fall in the number of varieties produced. However, from a consumer's viewpoint, the effect of lower input price is not ambiguous. Indeed, the gains from the fall in variety prices and a better allocation of resources associated with lower 
input price offset the losses due the reduction in the number of varieties available in the economy.

Our framework captures different mechanisms explaining the relationship between falling relative agricultural prices, concentration in many sectors of the food economy, and increasing average productivity in the food sector since the early 1900s until recently (2006). We believe that our framework may be useful for guiding future empirical analysis. It should be interesting to test empirically the impact of agricultural prices on the size and productivity distribution of food firms. 


\section{References}

Amiti, M., Konings, J., 2007. Trade Liberalization, Intermediate Inputs, and Productivity: Evidence from Indonesia. American Economic Review 97 (5), 1611-1638.

Bartelsman, E., Scarpetta, S., Schivardi, F., 2002. Comparative analysis of firm demographics and survival: Micro-level evidence for the OECD countries. Industrial and Corporate Change 14 (3), 365-391.

Blanchard, P., Huiban, J.-P., Mathieu, C., 2010. The dynamics of French food industries: productivity, sunk costs and firm exit. ALISS Working Paper.

Butault, J.-P., 2008. La relation entre prix agricoles et prix alimentaires. Revue française d'économie 23 (2), 215-241.

Chevassus-Lozza, E., Gaigné, C., Le Mener, L., 2012. Does input trade liberalization boost downstream firms' exports? Theory and firm-level evidence. Cahier de recherche/Working paper 3, RéseauSPAANetwork, Univ. of Laval.

Cotterill, R., 1999. Continuing Concentration in Food Industries Globally: Strategic Challenges to an Unstable Status Quo. Research Reports, Univ. of Connecticut, Food Marketing Policy Center.

Ericson, R., Pakes, A., 1995. Markov-Perfect Industry Dynamics: A Framework for Empirical Work. Review of Economic Studies 62 (1), 53-82.

Foster, L., Haltiwanger, J., Syverson, C., 2008. Reallocation, Firm Turnover, and Efficiency : Selection on Productivity or Profitability? The American economic review 98 (1), 394-425.

Gardner, B., 1992. Changing economic perspectives on the farm problem. Journal of Economic Literature 30 (1), 62-101.

Goldberg, P., Khandelwal, A., Pavcnik, N., Topalova, P., 2009. Trade liberalization and new imported inputs. American Economic Review 99 (2), 494-500.

Goldberg, P., Khandelwal, A., Pavcnik, N., Topalova, P., 2010. Imported Intermediate Inputs and Domestic Product Growth: Evidence from India. Quarterly Journal of Economics 125 (4), 1727-1767. 
Gopinath, M., Pick, D., Li, Y., 2004. An empirical analysis of productivity growth and industrial concentration in us manufacturing. Applied Economics 36 (1), 1-7.

Gopinath, M., Roe, T. L., Shane, M. D., 1996. Competitiveness of U.S. Food Processing: Benefits from Primary Agriculture. American Journal of Agricultural Economics $78(4), 1044$.

Halpern, L., Koren, M., Szeidl, A., 2009. Imported inputs and productivity. Center for Firms in the Global Economy (CeFiG) Working Papers.

Hopenhayn, H. A., 1992. Entry, Exit, and firm Dynamics in Long Run Equilibrium. Econometrica 60 (5), 1127-1150.

Jovanovic, B., 1982. Selection and the Evolution of Industry. Econometrica 50 (3), 649 670.

Jovanovic, B., Tse, C.-Y., 2010. Entry and exit echoes. Review of Economic Dynamics $13(3), 514-536$.

Kasahara, H., Lapham, B., 2008. Productivity and the decision to import and export: Theory and evidence. CESifo Working Paper Series No 2240.

Kugler, M., Verhoogen, E., 2009. Plants and imported inputs: New facts and an interpretation. American Economic Review 99 (2), 501-507.

MacDonald, J. M., 1986. Entry and exit on the competitive fringe. Southern Economic Journal, 640-652.

McCorriston, S., 2002. Why should imperfect competition matter to agricultural economists? European Review of Agricultural Economics 29 (3), 349-371.

Melitz, M. J., 2003. The Impact of Trade on Intra-Industry Reallocations and Aggregate Industry Productivity. Econometrica 71 (6), 1695-1725.

Morrison Paul, C. J., MacDonald, J., 2003. Tracing the effects of agricultural commodity prices and food costs. American Journal of Agricultural Economics 85 (3), 633-646.

Ollinger, M., Nguyen, S. V., Blayney, D., Chambers, B., Nelson, K., 2005. Structural Change in the Meat, Poultry, Dairy and Grain Processing Industries. Economic Research Report, Economic Research Service, USADA, Washington, DC. 
Raval, D., 2011. Estimation of a CES Production Function with Factor Augmenting Technology. miméo, 0-66.

Samaniego, R. M., 2010. Entry, Exit, and Investment-Specific Technical Change. American Economic Review.

Sexton, R. J., Lavoie, N., 2001. Food processing and distribution: an industrial organization approach. Handbook of agricultural economics. 


\section{Appendix A. Closed economy}

1. Zero profit condition. A firm enters the market as long as the expected value of entry is higher than the enter sunk cost. The expected profit of a firm prior to enter the market is given by $\left[1-G\left(\bar{\varphi}_{h}\right)\right] \tilde{\pi}_{h}$ where $\left[1-G\left(\bar{\varphi}_{h}\right)\right]$ is the probability to enter market and $\tilde{\pi}_{h}$ is the espected profit conditional on succesful entry. By plugging (6), and (10) into (11), we obtain

$$
\begin{aligned}
\tilde{\pi}_{h} & =\int_{\bar{\varphi}_{h}}^{\infty}\left[\frac{r_{h}(\varphi)}{\varepsilon}-\mathrm{f}_{d}\right] \frac{g(\varphi)}{1-G\left(\bar{\varphi}_{h}\right)} \mathrm{d} \varphi \\
& =\int_{\bar{\varphi}_{h}}^{\infty}\left[\frac{r_{h}(\varphi)}{r_{h}\left(\bar{\varphi}_{h}\right)} \frac{r_{h}\left(\bar{\varphi}_{h}\right)}{\varepsilon}-\mathrm{f}_{d}\right] \frac{g(\varphi)}{1-G\left(\bar{\varphi}_{h}\right)} \mathrm{d} \varphi
\end{aligned}
$$

Using $\left.r_{h}\left(\bar{\varphi}_{h}\right)=\varepsilon f_{d}, 26\right)$ becomes:

$$
\begin{aligned}
\tilde{\pi}_{h} & =\int_{\bar{\varphi}_{h}}^{\infty}\left[\frac{r_{h}(\varphi)}{r_{h}\left(\bar{\varphi}_{h}\right)} \mathrm{f}_{d}-\mathrm{f}_{d}\right] \frac{g(\varphi)}{1-G\left(\bar{\varphi}_{h}\right)} \mathrm{d} \varphi \\
& =\mathrm{f}_{d} \int_{\bar{\varphi}_{h}}^{\infty} \frac{r_{h}(\varphi)}{r_{h}\left(\bar{\varphi}_{h}\right)} \frac{g(\varphi)}{1-G\left(\bar{\varphi}_{h}\right)} \mathrm{d} \varphi-\mathrm{f}_{d}
\end{aligned}
$$

Knowing (7), we obtain:

$$
\tilde{\pi}_{h}=\frac{\mathrm{f}_{d}}{1-G\left(\bar{\varphi}_{h}\right)}\left(\frac{1}{\bar{\varphi}_{h}}+z_{h} \alpha\right)^{\varepsilon-1} \int_{\bar{\varphi}_{h}}^{\infty}\left(\frac{1}{\varphi}+z_{h} \alpha\right)^{1-\varepsilon} g(\varphi) \mathrm{d} \varphi-\mathrm{f}_{d}
$$

2. Existence and uniqueness of $\bar{\varphi}_{h}$. According to the free entry condition [1 $\left.G\left(\bar{\varphi}_{h}\right)\right] \tilde{\pi}_{h}=\delta \mathrm{f}_{e}$ and using (27) (see Appendix A.1), $\bar{\varphi}_{h}$ is implicitly defined by $\delta \mathrm{f}_{e}=$ $\mathrm{f}_{d} K\left(\bar{\varphi}_{h}\right)$ with

$$
K\left(\bar{\varphi}_{h}\right) \equiv\left(\bar{\varphi}_{h}^{-1}+\alpha z_{h}\right)^{\varepsilon-1}\left[\int_{\bar{\varphi}_{h}}^{\infty}\left(\varphi^{-1}+\alpha z_{h}\right)^{1-\varepsilon} g(\varphi) \mathrm{d} \varphi\right]-\left[1-G\left(\bar{\varphi}_{h}\right)\right]
$$

As in Melitz (2003), we have $\mathrm{d} K(\varphi) / \mathrm{d} \varphi<0$ when $\varphi>0$ (see Melitz, 2003, p. 1720, with $\alpha=0$ ) and

$$
\lim _{\varphi \rightarrow+\infty} \mathrm{f}_{d} K\left(\varphi_{h}\right)=0 \text { and } \lim _{\varphi \rightarrow 0} \mathrm{f}_{d} K\left(\varphi_{h}\right)=+\infty
$$

Then the curve $\mathrm{f}_{d} K\left(\varphi_{h}\right)$ only intersects with the curve $\delta \mathrm{f}_{e}$ once when $\varphi>0$ which ensures the existence and uniqueness of the equilibrium cut off $\bar{\varphi}_{h}>0$. 
3. Proof that $\partial \bar{\varphi}_{h} / \partial z_{h}<0$. Let $\Psi_{h} \equiv\left[1-G\left(\bar{\varphi}_{h}\right)\right] \tilde{\pi}_{h}$ such that:

$$
\Psi_{h}=\mathrm{f}_{d}\left(\frac{1}{\bar{\varphi}_{h}}+z_{h} \alpha\right)^{\varepsilon-1} \int_{\bar{\varphi}_{h}}^{\infty}\left(\frac{1}{\varphi}+z_{h} \alpha\right)^{1-\varepsilon} g(\varphi) \mathrm{d} \varphi-\left[1-G\left(\bar{\varphi}_{h}\right)\right] \mathrm{f}_{d}
$$

We must have $\Psi_{h}=\delta \mathrm{f}_{e}$ at equilibrium. By using the envelop theorem, the impact of intermediate goods price is as follows:

$$
\frac{\partial \bar{\varphi}_{h}}{\partial z_{h}}=-\frac{\partial \Psi_{h}}{\partial z_{h}}\left(\frac{\partial \Psi_{h}}{\partial \varphi}\right)^{-1}
$$

Because $\Psi_{h}=\mathrm{f}_{d} k(\varphi)[1-G(\varphi)]$, we have $\partial \Psi_{h} / \partial \varphi<0$ (see Appendix A.2). In addition, we have $\partial \Psi_{h} / \partial z_{h}=\left[1-G\left(\bar{\varphi}_{h}\right)\right] \partial \tilde{\pi}_{h} / \partial z_{h}$ where

$$
\begin{aligned}
\frac{\partial \tilde{\pi}_{h}}{\partial z_{h}}= & \mathrm{f}_{d}(\varepsilon-1) \alpha\left(\bar{\varphi}_{h}^{-1}+\alpha z_{h}\right)^{\varepsilon-1} \times \\
& {\left[\int_{\bar{\varphi}_{h}}^{\infty} \frac{\left(\varphi^{-1}+\alpha z_{h}\right)^{1-\varepsilon}}{\bar{\varphi}_{h}^{-1}+\alpha z_{h}} \mu_{h}(\varphi) \mathrm{d} \varphi-\int_{\bar{\varphi}_{h}}^{\infty} \frac{\left(\varphi^{-1}+\alpha z_{h}\right)^{1-\varepsilon}}{\varphi^{-1}+\alpha z_{h}} \mu_{h}(\varphi) \mathrm{d} \varphi\right]<0 }
\end{aligned}
$$

because $\varphi^{-1}+\alpha z_{h}<\bar{\varphi}_{h}^{-1}+\alpha z_{h}$ as long as $\varphi>\bar{\varphi}_{h}$. Consequently, $\partial \bar{\varphi}_{h} / \partial z_{h}<0$.

\section{Appendix B. Proof that imports of input equal to ex- ports of numeraire}

The total expenditure of a representative consumer is given by the size of the country $L$. In country $i=h, f$, we have

$$
L=\left[\int_{\bar{\varphi}_{i}}^{\infty} p_{i}(\varphi) y_{i}(\varphi) \mu_{i}(\varphi) \mathrm{d} \varphi\right] M_{i}+N_{i}
$$

The labor used in country $h$ is as follows:

$$
L=\left[\int_{\bar{\varphi}_{h}}^{\infty} \frac{y_{h}(\varphi)}{\varphi} \mu_{h}(\varphi) \mathrm{d} \varphi+\mathrm{f}_{d}\right] M_{h}+M_{h}^{e} \mathrm{f}_{e}+L_{h}^{N}
$$

whereas we have in country $f$ :

$L=\left[\int_{\bar{\varphi}_{f}}^{\infty} y_{f}(\varphi)\left(\frac{1}{\varphi}+z_{f} \alpha\right) \mu_{f}(\varphi) \mathrm{d} \varphi+\mathrm{f}_{d}\right] M_{f}+M_{h}^{e} \mathrm{f}_{e}+L_{f}^{N}+\left[\int_{\bar{\varphi}_{h}}^{\infty} y_{f}(\varphi) z_{f} \alpha \mu_{f}(\varphi) \mathrm{d} \varphi\right] M_{h}$

Knowing (31), (32), and $M_{h}^{e} \mathrm{f}_{e}=\Pi_{h}$, we obtain

$$
\Pi_{h}=\left[\int_{\bar{\varphi}_{h}}^{\infty} p_{h}(\varphi) y_{h}(\varphi) \mu_{h}(\varphi) \mathrm{d} \varphi\right] M_{h}-\left[\int_{\bar{\varphi}_{h}}^{\infty} \frac{y_{h}(\varphi)}{\varphi} \mu_{h}(\varphi) \mathrm{d} \varphi+\mathrm{f}_{d}\right] M_{h}+N_{h}-L_{h}^{N}
$$


Similarly, in country $f$, we have

$$
\Pi_{f}=(1-\rho)\left[\int_{\bar{\varphi}_{f}}^{\infty} p_{f}(\varphi) y_{f}(\varphi) \mu_{f}(\varphi) \mathrm{d} \varphi\right] M_{f}+N_{f}-\left[\int_{\bar{\varphi}_{h}}^{\infty} y_{f}(\varphi) z_{f} \alpha \mu_{f}(\varphi) \mathrm{d} \varphi\right] M_{h}-M_{f} \mathrm{f}_{d}-L_{f}^{N} .
$$

In addition, because profits are equal to operating profits minus fixed costs, we have

$$
\Pi_{h}=(1-\rho)\left[\int_{\bar{\varphi}_{h}}^{\infty} p_{h}(\varphi) y_{h}(\varphi) \mu_{h}(\varphi) \mathrm{d} \varphi\right] M_{h}-\mathrm{f}_{d} M_{h}
$$

in country $h$ and, in country $f$

$$
\Pi_{f}=(1-\rho)\left[\int_{\bar{\varphi}_{f}}^{\infty} p_{f}(\varphi) y_{f}(\varphi) \mu_{f}(\varphi) \mathrm{d} \varphi\right] M_{f}-\mathrm{f}_{d} M_{f}
$$

Plugging equations (34) into (36) leads to

$$
\begin{aligned}
& \rho\left[\int_{\bar{\varphi}_{h}}^{\infty} p_{h}(\varphi) y_{h}(\varphi) \mu_{h}(\varphi) \mathrm{d} \varphi\right] M_{h}-\left[\int_{\bar{\varphi}_{h}}^{\infty} \frac{y_{h}(\varphi)}{\varphi} \mu_{h}(\varphi) \mathrm{d} \varphi\right] M_{h}=L_{h}^{N}-N_{h} \\
\Leftrightarrow & {\left[\int_{\bar{\varphi}_{h}}^{\infty}\left(\frac{1}{\varphi}+z_{f} \alpha\right) y_{h}(\varphi) \mu_{h}(\varphi) \mathrm{d} \varphi\right] M_{h}-\left[\int_{\bar{\varphi}_{h}}^{\infty} \frac{y_{h}(\varphi)}{\varphi} \mu_{h}(\varphi) \mathrm{d} \varphi\right] M_{h}=L_{h}^{N}-N_{h} } \\
\Leftrightarrow & {\left[\int_{\bar{\varphi}_{h}}^{\infty} z_{f} \alpha y_{h}(\varphi) \mu_{h}(\varphi) \mathrm{d} \varphi\right] M_{h}=L_{h}^{N}-N_{h} }
\end{aligned}
$$

As a result, the amount of intermediate good used by firms in country $h$ equals the production of numeraire minus the amount of numeraire consumed in country $h$. In other words, imports of intermediate goods from country $f$ equal exports of numeraire to country $f$.

Plugging (35) into (37) involves for country $f$ :

$$
\left[\int_{\bar{\varphi}_{h}}^{\infty} z_{f} \alpha y_{h}(\varphi) \mu_{h}(\varphi) \mathrm{d} \varphi\right] M_{h}=N_{f}-L_{f}^{N}
$$

The amount of intermediate goods produced in country $f$ purchased by firms located in country $h$ is equal to the demand for numeraire minus the production of numeraire in country $f$. In other words, exports of intermediate goods to country $h$ equal imports of numeraire from country $h$.

This also implies that the amount of labor used to produce numeraire for export from country $h$ equals the amount of labor used to produce intermediate goods to serve country $h$. Thus, in both countries, the amount of labor available to produce final goods is the same. Hence,

Lemma 2. Under free input trade, the size in terms of jobs in the final sector is identical in both countries. 